\title{
Soil organic matter quality and composition in a postfire Scotch pine forest in Tolyatti, Samara region
}

\author{
Ekaterina Maksimova ${ }^{1,2}$, and Evgeny Abakumov ${ }^{1,2}$ \\ 1 Department of Applied Ecology, Faculty of Biology, St. Petersburg State University, \\ 16th Liniya V. O., 29, St. Petersburg, 199178, Russian Federation \\ 2 Institute of Ecology of Volga River Basin, Tolyatti, Russian Federation \\ Address correspondence and requests for materials to Ekaterina Maximova, \\ doublemax@yandex.ru
}

Citation: Maximova, E., and Abakumov, E. 2017. Soil organic matter quality and composition in a postfire Scotch pine forest in Tolyatti, Samara region. Bio. Comm. 62(3): 169-180. https://doi.org/10.21638/11701/ spbu03.2017.303

Author's information: Ekaterina Maximova, orcid.org/0000-0002-2449-2180; Researcher ID: O-8872-2014; Evgeny Abakumov, Dr. Sci., Professor, orcid.org/0000-0002-5248-9018, Researcher ID: B-5291-2013

Manuscript Editor: Prof. Cezary Kabala, Institute of Soil Science and Environmental Protection, Wroclaw University of Environmental and Life Sciences, Wroclaw, Poland;

Received: July 5, 2017;

Revised: November 21, 2017;

Accepted: November 22, 2017;

Copyright: ๑ 2017 Maximova, and Abakumov. This is an open-access article distributed under the terms of the License Agreement with Saint Petersburg State University, which permits to the authors an unrestricted distribution and self-archiving free of charge.

Funding: This work was supported by a grant of the Russian Scientific Foundation, project 17-16-01030. This study was partially supported by analytical analyses performed at the Centre for Magnetic Resonance and at the Centre for Chemical Analysis and Materials Research of Research Park of St. Petersburg State University.

Competing interests: The authors have declared that no competing interests exist.

\begin{abstract}
Evaluation of humus accumulation and humification rates was conducted on soils affected by surface and crown fires during 2010 forest fires near Tolyatti (Samara region, Russia). Three key soil plots were studied for estimating SOM quality changes under the forest fire effect. Total carbon and nitrogen content, as well as $C_{\text {humic acids }} / C_{\text {fulvic acids }}\left(C_{\mathrm{ha}} / \mathrm{C}_{\mathrm{fa}}\right)$ ratios, were estimated to evaluate the dynamics of soil recovery. Humic acid powders were extracted from soils and analyzed by elemental composition and ${ }^{13} \mathrm{C}$-NMR spectroscopy to assess changes in structure and composition. The data indicate that the burning of a forest floor and humic horizon led to humus losses and decreases in total carbon stocks and content. As a result of the fires, the content of humic acids in the pyrogenic horizon increased. Greater increases in the degree of organic matter humification were observed for surface fires than for crown fires. Fire also lead to the formation of humic acids with an increased proportion of aromatic compounds than in control soils, which indicates the degradation of carboxylic and aliphatic groups of molecules under the burning effect. This corresponds well with the decrease of the proportion of hydrogen when comparing the elemental composition of burned soil with that of mature soil.
\end{abstract}

Keywords: soils, wildfires, postfire soil development, humic acids, soil organic matter

\section{Introduction}

Forest ecosystems affected by wildfires show successional changes, which are caused by both internal and external environmental changes. Succession is defined as the gradual development of a plant community and soil in a changing environment. Investigation of soil properties in ongoing plant community successions is an informative tool for understanding and interpreting soil-biota interactions, and it provides effective solutions for the elaboration of recovery processes. A number of studies on successional changes and their relation to initial soil formation have been published (Huggett, 1998; Cerli et al., 2008; Abakumov, 2009; Abakumov, Maksimova, Lagoda and Koptseva, 2011; Abakumov and Frouz, 2009).

Soils play an essential role in determining biogeochemical Earth cycles, as well as hydrological and erosional cycles. Soils contribute to basic human needs such as food, clean water and clean air, and they are a major carrier of biodiversity; soils sustain life and can change a climate. Moreover, the soil system determines the goods, services and resources available to humankind (Mol and Keesstra, 2012; Keesstra et al., 2016).

Pyrogenic processes are widely distributed phenomena, significantly affecting pedogenesis and numerous environmental processes (Vasil'evskaya, 1986; Certini, 2005, 2014; Cerdà and Doerr, 2008; Certini et al., 2011; Pereira et al., 
2014, 2015). Numerous groups are studying the role of forest fires in the natural dynamics of forest cover because fires are the most important environmental factor determining the structure and dynamics of forest development and, hence, the environmental status of a forest. Soils subjected to extreme impacts are specific objects that attract great attention of researchers (Sorokin, 1983; Diaz-Ravina, 1996; Abakumov, Maksimova, Lagoda and Koptseva, 2011; Antipova and Prokhorova, 2012; Zenova et al., 2012). However, there have been few studies devoted to the assessment of the soil ecological state in subboreal ecosystems and, particularly, in insular pine stands within the forest-steppe zone immediately after forest fires.

As identified by previous works, fire has an important impact on soil properties (Certini, 2005, 2014; Mataix-Solera et al., 2011; Jain et al., 2012; Bergeron et al., 2013; Guénon et al., 2013; Dymov and Gabov, 2015; Maximova and Abakumov, 2015; Pereira et al., 2015; Pereira, Rein, and Martin, 2016; Keesstra et al., 2016; Van Eck et al., 2016). After a fire, there is an accumulation of ash on the topsoil (Pereira et al. 2014), leaching of some nutrients into deeper horizons (Bodi et al., 2014), over-compaction of the surface, accumulation of crusts, and transformation of soil structure (Mataix et al., 2011).

Soil organic matter (SOM) content is a key component of the carbon cycle in forest ecosystems and is of particular interest in pyrogenic associations. The most dynamic part of soil is organic matter, including the microbial community. These affect the soil's physical and chemical properties and become a driving factor in succession.

Changes in SOM caused by fire or high temperature lead to the formation of so-called "pyrogenic C", or pyromorphic humus (Gonzalez-Perez, González-Vila, Almendros, and Knicker, 2004). "Black carbon" forms during heating to $250-500^{\circ} \mathrm{C}$ with incomplete combustion of wood residues (Baldok and Smernik, 2002). Thus, fire significantly alters the molecular structure of various organic substances, resulting in the formation of new substances resistant to oxidation (Schulze, Wirth, and Heimann, 2000).

Gonzalez-Perez, González-Vila, Almendros, and Knicker (2004) have classified the following changes in humic substances in their comprehensive review of the impact of fire on soil organic matter:

- Total removal of external oxygen-containing functional groups, leading to the formation of substances with low solubility

- Decreased aliphatic chain length in humic acids and various hydrocarbons

- Increased degree of aromaticity in organic matter

- Structural changes in humic acids, including polymerization

- Formation of nitrogen-containing heterocycles
- Formation of a hardly hydrolyzable component, "black carbon".

Numerous studies (Schulze, Wirth, and Heimann, 2000; Almendros, Gonzalez-Vila, and Martın, 1990; Gonzalez-Perez, González-Vila, Almendros, and Knicker, 2004; Nadporozhskaya et al., 2006) suggest that the quality of SOM undergoes certain changes after fires, but these changes are incompletely understood and warrant further research. There are numerous data of carbon and nitrogen content and stocks dynamics after fires (Baldock and Smernik, 2002; Gonzalez-Perez, GonzálezVila, Almendros, and Knicker, 2004; Zhao et al., 2012; Michelloti and Miesel, 2015), but not many published results about the alteration of SOM quality (Certini et al. 2011; Mastrolonardo et al., 2015). Few works have been published regarding the investigation of the humic substances' molecular composition (Knicker, 2007; Alexis, Rumpel, and Knicker, 2010).

The working hypothesis of this research is that forest fires' influence on the SOM system is expressed not only in content and stocks of organic carbon and nitrogen but in the quality, namely on elemental and molecular composition scale, and there is a significant difference between the impact of surface and crown fires. Alteration of organic matter quality is essentially pronounced in its fraction compositions, assessed in the base of humicfulvic acids ratios as well by atomic ratio of humic acids and their molecular composition

In this context we aimed to characterize SOM dynamics after spontaneous forest fires occurred near Tolyatti city (Samara region, Russia) in 2010. In order to analyze a SOM system of postpyrogenic soils, the following objectives were set: (1) to assess the total humus content and group humus composition, and to analyze SOM quality indicators; (2) to carry out an elemental analysis of SOM and humic powders; and (3) to study ${ }^{13} \mathrm{C}-\mathrm{NMR}$ spectra of postpyrogenic soil humic acids, with special reference to the $\mathrm{C}$ functional groups.

\section{Materials and methods}

\section{STUDY MATERIALS}

The extreme summer temperatures of 2010 were critically important to the appearance of wildfires in Russia. Hot weather began in the middle of July and expanded to the whole area of European Russia, Ukraine and Eastern Europe. The extreme heat led to drought and wildfires in the vast territories of European and (later) Siberian Russia. Huge territories were occupied by wildfires, and there was an initiation of postfire soil formation which presented a specific type of secondary soil evolution.

The forest-steppe pine forests, which are typical in the semi-arid zone in spots (so-called "islands of pine forest in the steppe") near Tolyatti were investigated. 

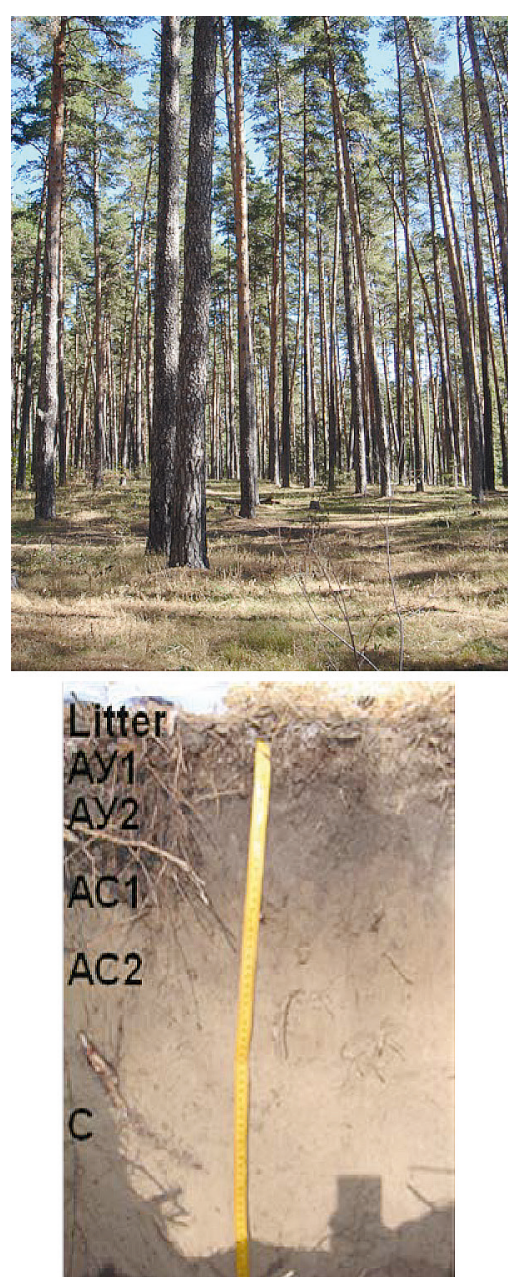

a

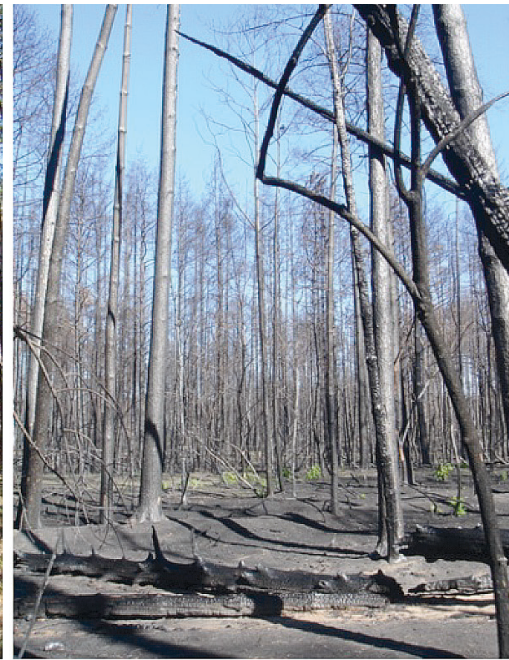

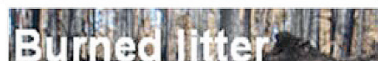

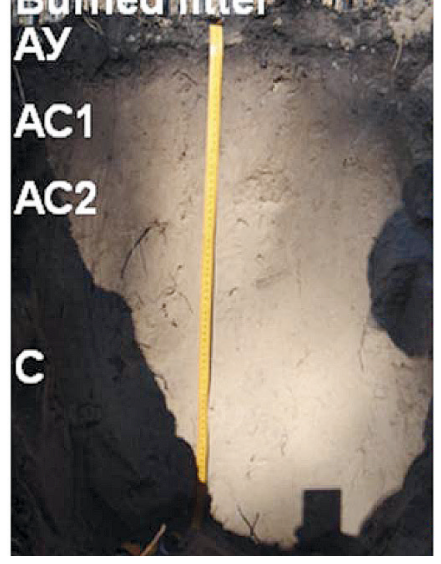

b
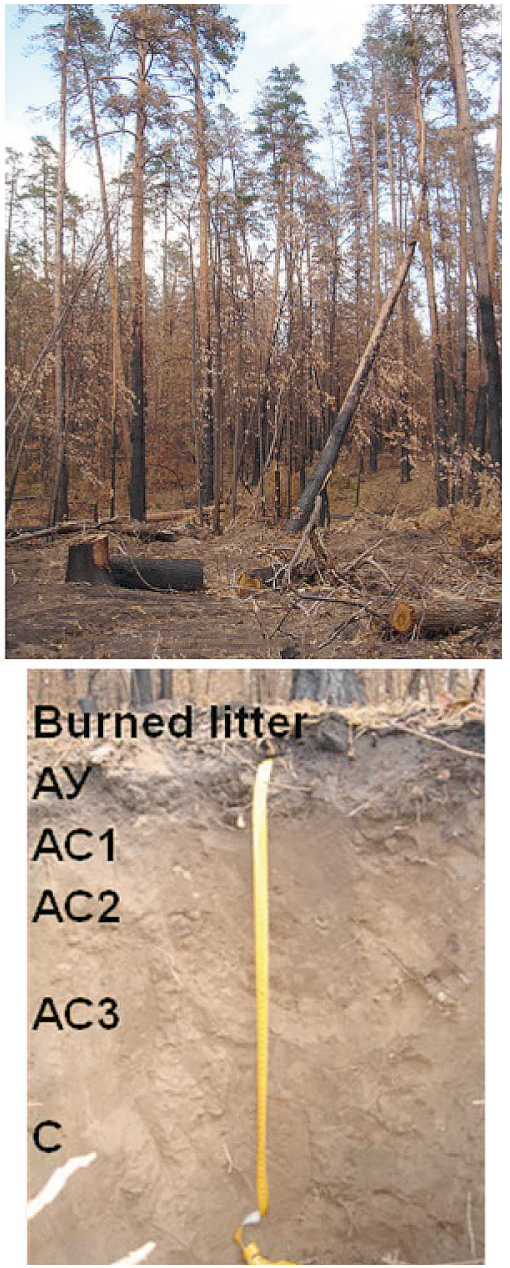

C

Fig. 1. Objects of the research and studied soils: $a-$ control plot, b - crown fire, c - surface fire

These pine forests are relics and are therefore critically important for protection, fire prevention and postfire management. Many of these pine forests have a status of regional protected areas.

The study plots located near Tolyatti, Samara region, were exposed to widespread forest fires in 2010. The study area is on an ancient alluvial-dune landscape in green recreation zones of the city (N 58 $39^{\prime} 44.55^{\prime \prime}$; E $39^{\circ} 17^{\prime} 48.95^{\prime \prime}, 179 \mathrm{~m}$ asl).

Three soil plots were studied for the estimation of SOM quality changes due to forest fire: surface forest fire, crown forest fire and control (Fig. 1). The three sampling scenarios (surface fire, crown fire, and control) were similar in terms of geology, topography, soil, and vegetation before the fires. Three soil pit replications were conducted at each plot. Studied soils were investigated in the period of 2010-2014. General chemical properties of studied soils were analyzed annually, elemental analysis of humic acids was done on samples from 2010, 2012 and 2014, and ${ }^{13} \mathrm{C}-\mathrm{NMR}$ spectra were investigated for isolated humic acids from 2012. Three analytical replicates were used.

The plants forming the lower forest synfolium (a shrubby, grassy, and mossy cover) burned down in the plot with surface fire. Crown fire covers the entire forest, from the soil surface to the tops of tree crowns, or passes through the trees and the underbrush, herbage, and moss layer. Seeds which are on the surface and in the solum (the upper soil horizons) can avoid the influence of a crown fire. Therefore, crown fire included burning at the surface and crown.

Sandy loam soils on Late Pleistocene alluvial Volga sands (Classification and diagnostics of Russian soils 2004) were studied, and have some features of an illuviation of spodic components without the formation of a separate podzolic horizon. These soils were classified as Psamment Entisol with weak features of illuviation process development and sand and clay contents of $70.5-86.4 \%$ and $0.3-2.6 \%$, respectively. Data on the general characteristics of the soils are given in Table 1 . 
Table 1. General chemical properties of soils 2010-2014, \pm after the mean value means SD

\begin{tabular}{|c|c|c|c|c|c|}
\hline $\begin{array}{l}\text { Hori- } \\
\text { zon }\end{array}$ & $\begin{array}{c}\text { Depth } \\
\text { (cm) }\end{array}$ & $\mathrm{pH}$ & $\begin{array}{c}\text { Ignition } \\
\text { loss value } \\
(\%)\end{array}$ & $\begin{array}{c}\text { Total } \\
\text { organic } \\
\text { carbon } \\
(\%)\end{array}$ & $\mathrm{C}_{\mathrm{ha}} / \mathrm{C}_{\mathrm{fa}}$ \\
\hline \multicolumn{6}{|c|}{ Surface fire (2010) } \\
\hline $\begin{array}{l}\text { Burned } \\
\text { litter }\end{array}$ & $0-5$ & $8.0 \pm 0.06$ & $5.68 \pm 0.95$ & $2.31 \pm 0.27$ & $2.14 \pm 0.13$ \\
\hline AY & $5-14$ & $6.2 \pm 0.32$ & $2.79 \pm 0.60$ & $1.21 \pm 0.50$ & $1.30 \pm 0.26$ \\
\hline \multirow[t]{3}{*}{$A C$} & $14-27$ & $6.0 \pm 0.21$ & $1.55 \pm 1.16$ & $0.75 \pm 0.48$ & nd \\
\hline & $27-36$ & $5.8 \pm 0.21$ & $0.80 \pm 0.49$ & $0.31 \pm 0.13$ & $\ll$ \\
\hline & $36-53$ & $5.3 \pm 0.31$ & $0.98 \pm 0.73$ & $0.22 \pm 0.05$ & « \\
\hline $\mathrm{C}$ & $53-73$ & $5.7 \pm 0.21$ & $0.81 \pm 0.05$ & $0.24 \pm 0.10$ & $\ll$ \\
\hline \multicolumn{6}{|c|}{ Crown fire (2010) } \\
\hline $\begin{array}{l}\text { Burned } \\
\text { litter }\end{array}$ & $0-5$ & $7.9 \pm 0.12$ & $5.45 \pm 1.41$ & $3.19 \pm 0.19$ & $1.95 \pm 0.34$ \\
\hline AY & $5-10$ & $5.9 \pm 0.38$ & $3.01 \pm 1.31$ & $1.42 \pm 0.31$ & $1.18 \pm 0.11$ \\
\hline \multirow[t]{2}{*}{$A C$} & $10-15$ & $5.9 \pm 0.25$ & $2.91 \pm 3.01$ & $0.78 \pm 0.07$ & nd \\
\hline & $15-24$ & $5.9 \pm 0.36$ & $0.86 \pm 0.29$ & $0.26 \pm 0.07$ & $\ll$ \\
\hline \multirow[t]{2}{*}{ C } & $24-44$ & $5.7 \pm 0.12$ & $0.66 \pm 0.14$ & $0.14 \pm 0.05$ & « \\
\hline & $44-64$ & $5.9 \pm 0.25$ & $0.63 \pm 0.09$ & $0.12 \pm 0.05$ & $\ll$ \\
\hline \multicolumn{6}{|c|}{ Control (2010) } \\
\hline Litter & $0-5$ & $6.5 \pm 0.10$ & $20.88 \pm 5.90$ & nd & $1.17 \pm 0.18$ \\
\hline \multirow[t]{2}{*}{ AY } & $5-8$ & $6.3 \pm 0.06$ & $2.71 \pm 1.34$ & $1.94 \pm 1.35$ & $0.67 \pm 0.13$ \\
\hline & $8-14$ & $6.2 \pm 0.23$ & $1.57 \pm 0.82$ & $0.78 \pm 0.33$ & nd \\
\hline \multirow[t]{2}{*}{$A C$} & $14-23$ & $6.1 \pm 0.23$ & $0.66 \pm 0.50$ & $0.33 \pm 0.10$ & $\ll$ \\
\hline & $23-33$ & $5.9 \pm 0.20$ & $0.57 \pm 0.12$ & $0.15 \pm 0.02$ & « \\
\hline \multirow[t]{2}{*}{ C } & $33-50$ & $5.7 \pm 0.12$ & $0.46 \pm 0.01$ & $0.21 \pm 0.03$ & $«$ \\
\hline & $50-70$ & $5.8 \pm 0.31$ & $0.52 \pm 0.17$ & $0.15 \pm 0.05$ & $«$ \\
\hline \multicolumn{6}{|c|}{ Surface fire (2012) } \\
\hline $\begin{array}{l}\text { Burned } \\
\text { litter }\end{array}$ & $0-4$ & $7.9 \pm 0.23$ & $4.39 \pm 3.09$ & $3.05 \pm 0.07$ & $2.14 \pm 0.13$ \\
\hline AY & $4-15$ & $6.6 \pm 0.11$ & $1.31 \pm 0.13$ & $1.51 \pm 0.05$ & $1.37 \pm 0.05$ \\
\hline \multirow[t]{3}{*}{$A C$} & $15-25$ & $5.4 \pm 0.19$ & $0.84 \pm 0.15$ & $0.72 \pm 0.27$ & nd \\
\hline & $25-35$ & $5.5 \pm 0.10$ & $0.66 \pm 0.23$ & $0.20 \pm 0.15$ & « \\
\hline & $35-55$ & $5.7 \pm 0.07$ & $0.79 \pm 0.29$ & $0.23 \pm 0.03$ & « \\
\hline $\mathrm{C}$ & $55-70$ & $5.8 \pm 0.15$ & nd & $0.50 \pm 0.09$ & $\ll$ \\
\hline \multicolumn{6}{|c|}{ Crown fire (2012) } \\
\hline $\begin{array}{l}\text { Burned } \\
\text { litter }\end{array}$ & $0-5$ & $6.4 \pm 0.46$ & $4.20 \pm 0.50$ & $2.47 \pm 0.05$ & $1.78 \pm 0.31$ \\
\hline AY & $5-13$ & $5.5 \pm 0.53$ & $1.94 \pm 1.24$ & $1.12 \pm 0.06$ & $1.15 \pm 0.07$ \\
\hline \multirow[t]{2}{*}{$A C$} & $13-17$ & $5.2 \pm 0.35$ & $0.91 \pm 0.35$ & $0.82 \pm 0.32$ & nd \\
\hline & $17-25$ & $5.2 \pm 0.17$ & $0.59 \pm 0.48$ & $0.38 \pm 0.25$ & $\ll$ \\
\hline \multirow[t]{2}{*}{ C } & $25-45$ & $4.7 \pm 0.35$ & $0.69 \pm 0.52$ & $0.27 \pm 0.11$ & « \\
\hline & $45-60$ & $5.2 \pm 0.35$ & nd & $0.26 \pm 0.06$ & « \\
\hline \multicolumn{6}{|c|}{ Control (2012) } \\
\hline Litter & $0-5$ & $6.1 \pm 0.14$ & $16.65 \pm 4.88$ & nd & $1.08 \pm 0.53$ \\
\hline \multirow[t]{2}{*}{ AY } & $5-10$ & $5.9 \pm 0.07$ & $2.21 \pm 0.71$ & $1.88 \pm 0.08$ & $0.72 \pm 0.26$ \\
\hline & $10-15$ & $5.8 \pm 0.07$ & $0.94 \pm 0.22$ & $0.74 \pm 0.31$ & nd \\
\hline \multirow[t]{2}{*}{$A C$} & $15-25$ & $5.6 \pm 0.07$ & $0.51 \pm 0.17$ & $0.26 \pm 0.08$ & $«$ \\
\hline & $25-45$ & $5.7 \pm 0.42$ & $0.48 \pm 0.20$ & $0.12 \pm 0.00$ & « \\
\hline C & $45-55$ & $5.1 \pm 0.14$ & nd & $0.19 \pm 0.10$ & « \\
\hline \multicolumn{6}{|c|}{ Surface fire (2014) } \\
\hline $\begin{array}{l}\text { Burned } \\
\text { litter }\end{array}$ & $0-3$ & $7.5 \pm 0.40$ & nd & $2.94 \pm 0.45$ & $1.90 \pm 0.08$ \\
\hline AY & $3-12(18)$ & $6.2 \pm 0.38$ & $\ll$ & $1.21 \pm 0.17$ & $1.36 \pm 0.02$ \\
\hline \multirow[t]{2}{*}{$A C$} & $12(18)-20$ & $5.3 \pm 0.18$ & « & $0.71 \pm 0.13$ & nd \\
\hline & $20-35$ & $5.4 \pm 0.09$ & $\ll$ & $0.23 \pm 0.06$ & $\ll$ \\
\hline $\mathrm{C}$ & $35-50$ & $5.2 \pm 0.05$ & $\ll$ & $0.22 \pm 0.00$ & « \\
\hline
\end{tabular}

\begin{tabular}{|c|c|c|c|c|c|}
\hline \multicolumn{6}{|c|}{ Crown fire (2014) } \\
\hline $\begin{array}{l}\text { Burned } \\
\text { litter }\end{array}$ & $0-4$ & $6.4 \pm 0.76$ & nd & $2.58 \pm 0.39$ & $1.72 \pm 0.07$ \\
\hline AY & $4-10$ & $5.5 \pm 0.05$ & « & $1.35 \pm 0.20$ & $1.14 \pm 0.11$ \\
\hline \multirow[t]{2}{*}{$A C$} & $10-18$ & $5.4 \pm 0.26$ & « & $0.79 \pm 0.07$ & nd \\
\hline & $18-30$ & $5.5 \pm 0.40$ & « & $0.28 \pm 0.05$ & $\ll$ \\
\hline C & $30-50$ & $5.2 \pm 0.52$ & $\ll$ & $0.10 \pm 0.03$ & « \\
\hline \multicolumn{6}{|c|}{ Control (2014) } \\
\hline Litter & $0-5$ & $6.5 \pm 0.33$ & nd & $4.36 \pm 1.37$ & $1.14 \pm 0.11$ \\
\hline AY & $5-16$ & $5.9 \pm 0.08$ & 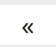 & $1.94 \pm 0.58$ & $0.70 \pm 0.02$ \\
\hline \multirow[t]{2}{*}{$A C$} & $16-30$ & $5.5 \pm 0.30$ & « & $0.75 \pm 0.06$ & nd \\
\hline & $30-45$ & $5.3 \pm 0.55$ & « & $0.31 \pm 0.13$ & $\ll$ \\
\hline C & $45-55$ & $5.5 \pm 0.24$ & « & $0.10 \pm 0.00$ & « \\
\hline
\end{tabular}

The control plot contained plant cover and soil unaffected by wildfire and was situated $1 \mathrm{~km}$ away from the fires.

\section{LABORATORY METHODS}

Sampling and descriptions of soil and vegetation were carried out three times: in September 2010, after the removal of the territory's state of emergency; in September 2012; and October 2014. The sampling points were constant. Soil samples were taken at the three plots at a depth of $0-15 \mathrm{~cm}$.

Sampling and descriptions of plant communities and soil profiles were conducted according to standard methodical guidelines (Vorobyova, 2006). Soil color was evaluated according the Munsell color chart method in a laboratory with air-dried soil samples (Cleland, 2004; Munsell, 1912). All soil parameters were studied on fine earth soil after being passed through a $2-\mathrm{mm}$ sieve. Total organic carbon (TOC) and nitrogen content were determined by using a C-H-N analyzer of the fine earth.

The general characteristics of the soils, including the chemical and physical parameters, were determined by standard methods (Methods of Soil Analysis, 1996). Light SOM fraction was evaluated by the density fractionation method. Humic powders were isolated in accordance with IHSS standard procedures (http://www. humicsubstances.org/). Humic acids were extracted from each soil sample according to the following procedure (Schnitzer, 1982). Briefly, humic acids were extracted with $0.1 \mathrm{M} \mathrm{NaOH}$ (soil:solution mass ratio $1: 10$ ) under nitrogen gas. After 24 hours of shaking, the alkaline supernatant was separated from the soil residue by centrifugation at $1516 \mathrm{~g}$ for $20 \mathrm{~min}$ and acidified to $\mathrm{pH} 1$ with $6 \mathrm{M} \mathrm{HCl}$ to induce humic acid precipitation. The supernatant (containing fulvic acids) was separated from the precipitate (containing humic acids) by centrifugation at $1516 \mathrm{~g}$ for $15 \mathrm{~min}$. The humic acids were dissolved in $0.1 \mathrm{M} \mathrm{NaOH}$ and shaken for 4 hours un- 
der nitrogen gas, and then solids were removed by centrifugation. The humic acid solution was acidified again with $6 \mathrm{M} \mathrm{HCl}$ to $\mathrm{pH} 1$, and the precipitated humic acids were isolated by centrifugation. The humic acids were demineralized by shaking overnight in $0.1 \mathrm{M} \mathrm{HCl} 0.3 \mathrm{M}$ HF (solid:solution ratio 1:1), repeatedly washed with deionized water until $\mathrm{pH} 3$ was reached, and freeze-dried. Humic acids were characterized for their elemental composition (C, N, H, and S) using a Euro EA3028-HT analyzer. Data were corrected for water and ash content. Oxygen content was calculated by difference. The calculations of the atomic percentages; the $\mathrm{C} / \mathrm{N}, \mathrm{H} / \mathrm{N}$, and $\mathrm{O} / \mathrm{C}$ atomic ratios; and the degree of oxidation $(\omega)$ of the humic acids and fulvic acids were based on a manual on SOM research (Orlov and Grishina, 1981). Caloricity value was calculated using Aliev's formula (Orlov, 1985) or Mendeleev's formula (Zikeev and Korelin, 1948). Van Krevelen diagrams of humic acids were drawn according to Orlov, Sadovnikova, and Sukhanova (2005).

Indicators of humic acids caloricity values were determined by the following empirical formulas:

$$
\begin{aligned}
& \mathrm{Q}=90[\mathrm{C}]+34.4[\mathrm{H}]-50(0.87[\mathrm{O}]-4[\mathrm{~N}]) \\
& \text { S.A. Aliev's formula }
\end{aligned}
$$

where $\mathrm{Q}=$ caloric value, in $\mathrm{kcal} / \mathrm{kg}$; and $[\mathrm{C}],[\mathrm{H}],[\mathrm{O}]$, $[\mathrm{N}]=$ percentage of carbon, hydrogen, oxygen and nitrogen, respectively, in the humic powder;

$$
\begin{aligned}
& \mathrm{Q}=81[\mathrm{C}]+300[\mathrm{H}]-26[\mathrm{O}], \\
& \text { D. I. Mendeleev's formula }
\end{aligned}
$$

where $\mathrm{Q}=$ caloric value of organic matter, in $\mathrm{kcal} / \mathrm{kg}$; and $[\mathrm{C}],[\mathrm{H}],[\mathrm{O}]=$ mass percent of carbon, hydrogen and oxygen in the humic powder.

${ }^{13} \mathrm{C}$-NMR spectra of humic acids were measured with a Bruker Avance 500 NMR spectrometer (Karlsruhe, Germany, 2003) in a $4-\mathrm{mm} \mathrm{ZrO} 2$ rotor. The magic angle spinning speed was $20 \mathrm{kHz}$ in all cases, and the nutation frequency of carbon fields for crosspolarization was $\mathrm{u} 1 / 2 \mathrm{p} 1 / 462.5 \mathrm{kHz}$. Repetition delay and number of scans were 3 s. Groups of structural compounds were identified by the chemical shift values: $190-170 \mathrm{ppm}$ - carboxyl group and amidic carbonyl; 170-150 ppm - aromatic carbon of phenols and phenol esters; 150-135 ppm - alkyl-aromatic; 135$108 \mathrm{ppm}$ - protonized aromatic carbon and bridgehead carbon; $108-100$ ppm - cellulose anomeric carbon and hemiacetal carbon; 100-70 ppm - resonance region of $\mathrm{C}-\mathrm{H}$ bonds, secondary alcohols, and other carbon atoms bound to oxygen; 70-50 ppm - methyl group resonance region of aliphatic and aromatic ethyl ethers, amino acid carbons, and methyl esters of carboxylic groups; 50$32 \mathrm{ppm}-$ resonance region of quarternal carbon and $\mathrm{CH}$ carbons; 32-27 ppm - resonance region of $\mathrm{CH}$ al- kyl structures in transconformation; 27-10 ppm - resonance region of alkyl methyls and $\mathrm{CH}$ units. The degree of aromaticity was calculated as the sum of the signals in the 100-170 and 183-190 ppm regions, whereas aliphatic compounds were in the $0-100$ and $164-183 \mathrm{ppm}$ regions (Lodygin, 2016).

\section{Results}

Humus degradation of the upper horizons was clearly visible by means of the ignition loss value. Ignition loss was more than $20.00 \%$ in the upper layer in the control plot (Table 1), but only $5.45 \%$ in the crown fire and $5.68 \%$ in the surface fire.

Since it is impossible to measure the level of humus accumulation in the litter of the control plot by traditional SOM content methods, the ignition loss value indicates the presence or absence of soil humus losses. However, the carbon content in the ash (burned litter) makes it possible to compare the results of surface and crown fire impact (Table 1). The SOM content in the surface fire ash in $2010(2.31 \pm 0.27 \%)$ was less than that in the crown fire ash $(3.19 \pm 0.19 \%)$. A similar trend was observed in the humus pyrogenic horizons: the surface fire carbon content was $1.21 \pm 0.50 \%$ and the crown fire $-1.42 \pm 0.31 \%$. Thus, more intensive losses of organic matter occurred as a result of surface fire, when there is a complete burning of the litter and upper horizon.

The carbon content in the soil after the surface fire increased in 2012 to $3.05 \%$ in the burned litter and $1.51 \%$ in the humus horizon due to the presence of new organic matter in the litter. The crown fire soil was characterized by an absence of new incoming litter, as well as by surface water erosion which was diagnosed by morphological methods and confirmed by carbon content analysis: carbon content decreased from 3.19 to $2.47 \%$ in the ash and from 1.42 to $1.12 \%$ in the humus horizon. The changes in SOM carbon content reversed in 2014: the surface fire plot decreased to $2.94 \%$ in the ash and $1.21 \%$ in the humus horizon, whereas the crown fire plot increased to $2.58 \%$ in the burned litter and $1.35 \%$ in the humus horizon. However, an accumulation of organic matter with new litter was still visible at the surface fire plot. Diverse factorial influences resulted in a strong heterogeneity of soil properties.

As for the mineral horizons, carbon content in general was comparable to similar indicators of the control plot. High temperatures had little impact on mineral horizons due to the very low thermal conductivity of the litter.

The $\mathrm{C}_{\mathrm{ha}}$ to $\mathrm{C}_{\mathrm{fa}}$ ratio of the upper soil layers changed as a result of the fires (Table 1). Information about the SOM quality according to the criteria of Orlov, Sadovnikova, and Sukhanova (2005) of the studied soils is shown in Table 2. 


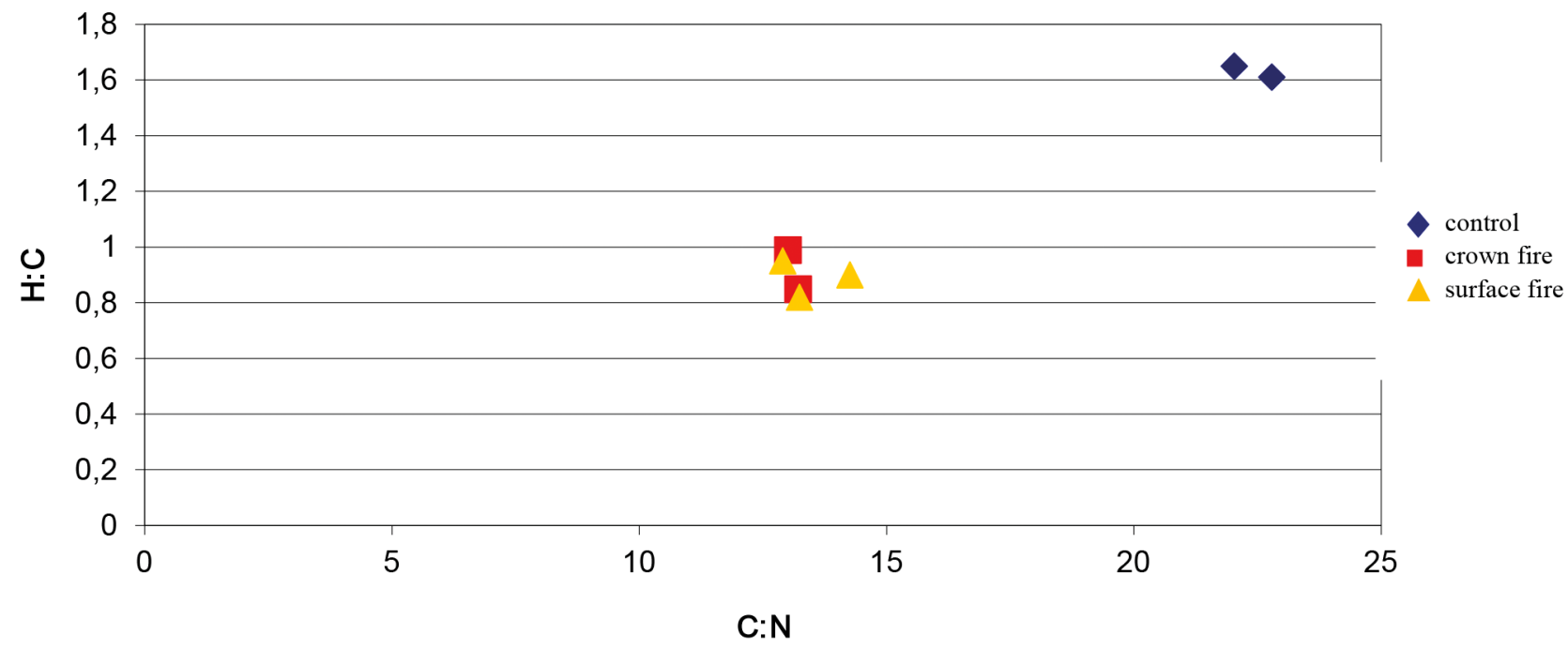

Fig. 2. H/C-C/N ratio in upper horizons of soil

Table 2. SOM Quality indicators

\begin{tabular}{|c|c|c|c|c|c|}
\hline Situation & $\begin{array}{l}\text { Humus content in } \\
\text { humus horizons (\%) }\end{array}$ & $\begin{array}{l}\text { Humus depthwise } \\
\text { distribution }\end{array}$ & $\begin{array}{l}\text { Nitrogen enrichment of } \\
\text { humus (C:N ratio) }\end{array}$ & $\begin{array}{c}\text { Degree of } \\
\text { humification, } \mathrm{C}_{\mathrm{ha}} / \\
\mathrm{C}_{\text {total }} * 100 \%\end{array}$ & Type of humus, $C_{h a}: C_{f a}$ \\
\hline \multicolumn{6}{|c|}{2010} \\
\hline Surface fire & Low-low & Sharply decreasing & Low & High & Humic \\
\hline Crown fire & Low-low & Sharply decreasing & Low & Middle & Fulvic-humic \\
\hline Control & Low & Sharply decreasing & Low-low & Middle & $\begin{array}{l}\text { Fulvic-humic (in lower } \\
\text { horizons - humic-fulvic) }\end{array}$ \\
\hline \multicolumn{6}{|c|}{2012} \\
\hline Surface fire & Low & Sharply decreasing & $\mathrm{nd}$ & Middle & Fulvic-humic \\
\hline Crown fire & Low & Sharply decreasing & nd & High & Humic \\
\hline Control & Low & Sharply decreasing & nd & Middle & Humic-fulvic \\
\hline
\end{tabular}

Table 3. Elemental analysis of soil samples of upper horizons

\begin{tabular}{l|c|c|c|c|c|c|c|c}
\hline \multicolumn{1}{c|}{ Sample } & $\mathbf{C}, \%$ & $\mathbf{N}, \%$ & $\mathbf{H}, \%$ & [C] $^{*}$ & {$[\mathbf{H}]^{*}$} & {$[\mathbf{N}]^{*}$} & $\mathbf{C : N}$ & $\mathbf{H : C}$ \\
\hline control & 26.23 & 1.36 & 3.6 & 2.18 & 3.56 & 0.10 & 22.41 & 1.63 \\
crown fire & 4.47 & 0.40 & 0.34 & 0.37 & 0.34 & 0.02 & 13.10 & 0.92 \\
surface fire & 6.55 & 0.57 & 0.49 & 0.54 & 0.49 & 0.04 & 13.47 & 0.89 \\
\hline
\end{tabular}

* atomic percent

Table 4. Elemental analysis of humic acids

\begin{tabular}{|c|c|c|c|c|c|c|c|c|c|c|c|c|c|c|}
\hline Sample & $\mathrm{C}, \%$ & $\mathrm{~N}, \%$ & $\mathrm{H}, \%$ & $0, \%$ & {$[\mathrm{C}]$} & {$[\mathrm{H}]$} & {$[N]$} & [0] & C:N & $\mathrm{H}: \mathrm{C}$ & O:C & $\begin{array}{c}\text { Caloric value } \\
\text { (Mendeleev), } \\
\text { kcal/kg }\end{array}$ & $\begin{array}{c}\text { Caloric value } \\
\text { (Aliev), kcal/ } \\
\text { kg }\end{array}$ & $\begin{array}{l}\text { Oxida- } \\
\text { tion } \\
\text { degree }\end{array}$ \\
\hline \multicolumn{15}{|c|}{ humic acids-2010 } \\
\hline control & 54.70 & 4.51 & 5.52 & 35.28 & 36.30 & 43.56 & 2.56 & 17.57 & 14.93 & 1.20 & 0.48 & 5169 & 4958 & -0.23 \\
\hline crown fire & 57.50 & 5.60 & 4.04 & 32.85 & 42.60 & 35.58 & 3.56 & 18.26 & 11.98 & 0.84 & 0.43 & 5016 & 5484 & 0.02 \\
\hline surface fire & 55.31 & 5.61 & 4.36 & 34.72 & 40.06 & 37.59 & 3.48 & 18.87 & 11.50 & 0.94 & 0.47 & 4887 & 5218 & -0.01 \\
\hline \multicolumn{15}{|c|}{ humic acids-2012 } \\
\hline control & 50.39 & 3.56 & 4.88 & 41.17 & 35.38 & 40.78 & 2.14 & 21.70 & 16.54 & 1.15 & 0.62 & 4477 & 5414 & 0.07 \\
\hline crown fire & 52.34 & 4.75 & 3.74 & 39.18 & 40.18 & 34.12 & 3.12 & 22.57 & 12.86 & 0.85 & 0.56 & 4342 & 5789 & 0.28 \\
\hline surface fire & 52.02 & 4.91 & 3.72 & 39.36 & 40.02 & 34.02 & 3.24 & 22.72 & 12.36 & 0.85 & 0.56 & 4306 & 5791 & 0.28 \\
\hline \multicolumn{15}{|c|}{ humic acids-2014 } \\
\hline control & 50.54 & 3.57 & 4.24 & 41.66 & 37.37 & 37.24 & 2.26 & 23.12 & 16.51 & 1.00 & 0.62 & 4281 & 5408 & 0,24 \\
\hline crown fire & 52.58 & 4.74 & 3.48 & 39.20 & 41.26 & 32.47 & 3.18 & 23.08 & 12.94 & 0.78 & 0.56 & 4284 & 5800 & 0,34 \\
\hline surface fire & 51.44 & 4.93 & 3.31 & 40.32 & 41.05 & 31.41 & 3.38 & 24.16 & 12.17 & 0.76 & 0.59 & 4111 & 5729 & 0,41 \\
\hline
\end{tabular}

* atomic percent 


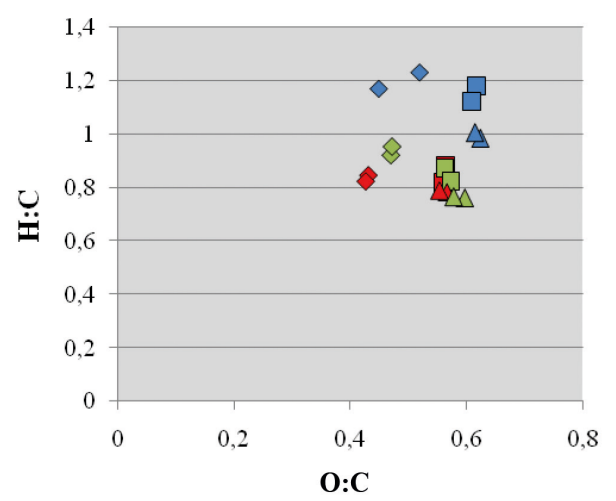

Fig. 3. H/C-O/C ratio of $\mathrm{HA}$

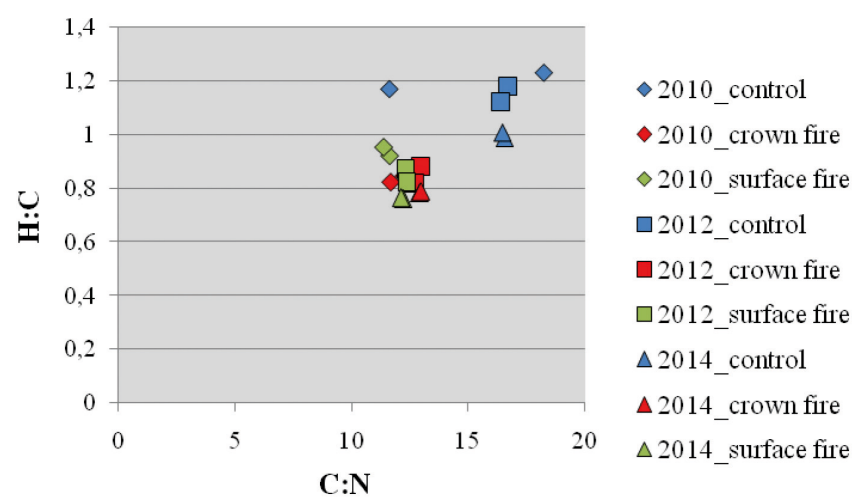

Fig. 4. H/C-C/N ratio of HA

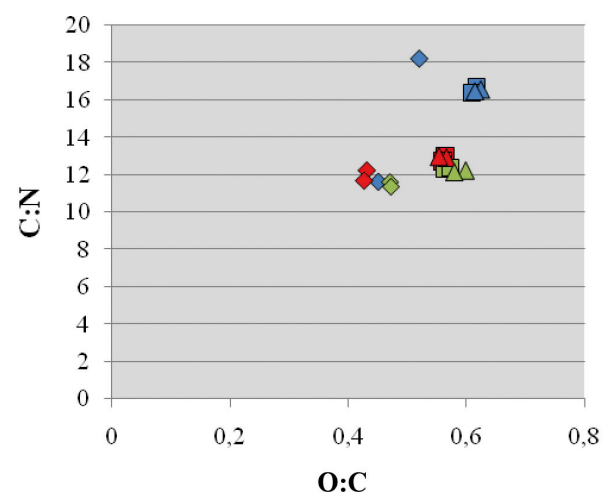

$\checkmark 2010 \_$control

$\checkmark 2010$ crown fire

$\diamond 2010 \_$surface fire

口2012_control

ם2012_crown fire

$\square 2012 \_$surface fire

$\Delta 2014$ control

$\Delta 2014$ crown fire

$\Delta 2014 \_$surface fire

Fig. 5. $\mathrm{C} / \mathrm{N}-\mathrm{O} / \mathrm{C}$ ratio of $\mathrm{HA}$

Table 5. Total content and elemental analysis of light fraction of soils

\begin{tabular}{|c|c|c|c|c|c|c|c|c|c|c|}
\hline Sample & Light fraction weight & Content (\% from humus content) & C, \% & $N, \%$ & $\mathrm{H}, \%$ & [C] & {$[\mathrm{H}]$} & {$[\mathrm{N}]$} & C:N & $\mathrm{H}: \mathrm{C}$ \\
\hline \multicolumn{11}{|c|}{2010} \\
\hline control & 16.68 & 20.05 & 34.12 & 4.95 & 5.44 & 33.11 & 62.77 & 4.12 & 8.04 & 1.90 \\
\hline crown fire & 20.09 & 12.18 & 26.70 & 1.64 & 3.50 & 38.29 & 59.69 & 2.02 & 18.99 & 1.56 \\
\hline surface fire & 15.26 & 13.67 & 27.73 & 1.92 & 3.17 & 41.34 & 56.20 & 2.45 & 16.85 & 1.36 \\
\hline \multicolumn{11}{|c|}{2011} \\
\hline control & 14.56 & 22.26 & 28.60 & 1.73 & 3.68 & 38.73 & 59.26 & 2.01 & 19.28 & 1.53 \\
\hline crown fire & 12.81 & 15.07 & 25.71 & 1.70 & 3.40 & 38.03 & 59.81 & 2.16 & 17.64 & 1.57 \\
\hline surface fire & 13.87 & 18.77 & 38.50 & 6.17 & 5.77 & 34.25 & 61.04 & 4.70 & 7.28 & 1.78 \\
\hline \multicolumn{11}{|c|}{2012} \\
\hline control & 19.53 & 17.12 & 30.17 & 3.56 & 3.16 & 42.61 & 53.08 & 4.31 & 9.88 & 1.24 \\
\hline crown fire & 16.75 & 13.89 & 31.16 & 3.36 & 3.34 & 42.25 & 53.85 & 3.90 & 10.82 & 1.27 \\
\hline surface fire & 9.54 & 21.87 & 30.37 & 3.40 & 3.26 & 42.15 & 53.80 & 4.04 & 10.42 & 1.28 \\
\hline
\end{tabular}

Results of an elemental analysis of SOM and humic powders (Tables 3,4$)$ separated from the litter material testify to the following regularities, depending on the type of fire and in comparison with the control plot.

SOM contained much more carbon, nitrogen and hydrogen (Table 3), testifying to the oxidation of organic matter and general humus degradation in the postfire plots. The crown fire plot was characterized by a slightly greater loss of all these elements. In the diagram of $\mathrm{H} / \mathrm{C}$ and $\mathrm{C} / \mathrm{N}$ atomic ratios (2010) (Table 3, Fig. 2), the group of organic matter of the control plot is brightly expressed. The most expressed process of SOM transformation was oxygen loss, which is a quite logical result of thermal oxidation.
The charts of the atomic ratios (Figs. 3-5, Table 4) indicate that the humic acids of postfire soils had significantly different elemental compositions than those of the control soil.

An indicator of the amount of "detrital" fine humus is the content of light fractions of SOM. This fraction is presented by raw humus, free organic matter of slightly decomposed organic remnants or black carbon fraction. The light fraction of SOM is allocated during the density fractionation of SOM.

The light fraction content in upper soil horizons affected by wildfires in 2010 was less than in the control plot (Table 5). The average content of light fraction in this case ranges from 9 to $20 \%$. It testifies that well- 


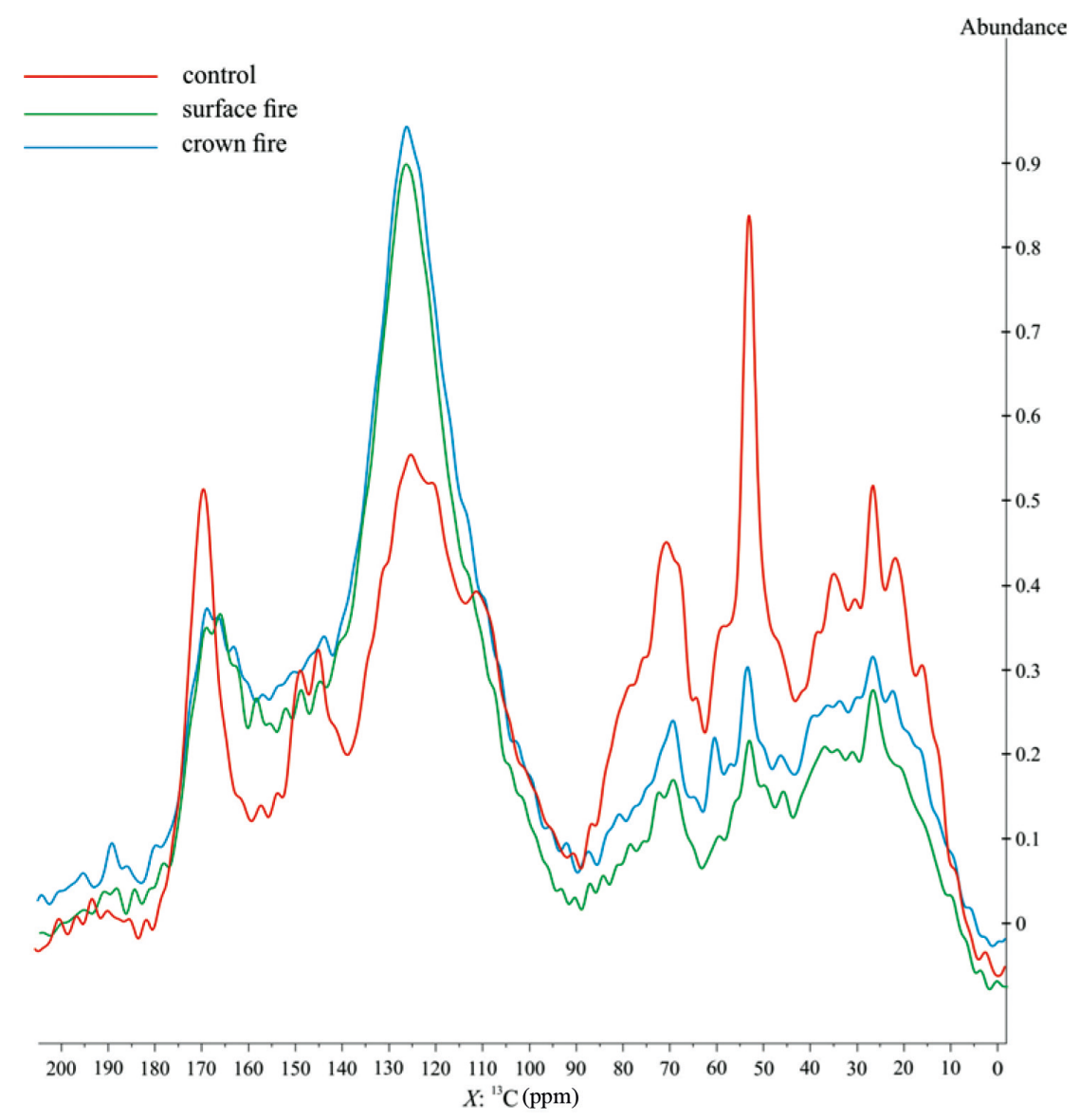

Fig. 6. 13C-NMR spectra of isolated humic acids

Table 6. Proportion of aromatic and aliphatic carbon in humic acids from analysis of 13C NMR spectra

\begin{tabular}{l|c|c}
\hline \multicolumn{1}{c|}{ Sample } & Aromatic, \% & Aliphatic, \% \\
\hline Control & 43 & 57 \\
Surface fire & 65 & 35 \\
Crown fire & 64 & 36 \\
\hline
\end{tabular}

decomposed humus forms dominate in organic matter of studied soils. The light fraction content at surface fire $(9-13 \%)$ is less than at crown fire $(12-16 \%)$ and much less than at control (16-19\%). Thus, black carbon is also present as a part of light fractions of SOM.

${ }^{13} \mathrm{C}-\mathrm{NMR}$ spectra of humic acids of the upper horizons in studied soils (2010) (Fig. 6) were analyzed with the aim of analyzing the relationship between elemental composition and structural features of HA. Interpretation of the spectra is given in Tables 6 and 7. Table 6 testifies that the aliphatic part is the main structural part of the humic acids in control soils, whereas the degree of aromaticity of humic acid molecules significantly increases as a result of wildfires.

\section{Discussion}

SOM content, as a key component of the carbon cycle in forest ecosystems, is of particular interest in pyrogenic soil-plant associations. The greatest impact is observed
Table 7. Carbon species in humic substances, $\%$

\begin{tabular}{l|c|c|c}
\hline \multicolumn{1}{c|}{ Chemical shifts, ppm } & Control & Surface fire & Crown fire \\
\hline $\begin{array}{l}\text { 10-27 ppm } \\
\text { alkyl methyls and CH units }\end{array}$ & 12 & 7 & 8 \\
$\begin{array}{l}27-32 \text { ppm } \\
\text { CH alkyl structures in } \\
\text { transconformation }\end{array}$ & 4 & 2 & 3 \\
$\begin{array}{l}32-50 \text { ppm } \\
\text { quarternal carbon and CH } \\
\text { carbons }\end{array}$ & 11 & 7 & 7 \\
$\begin{array}{l}\text { 50-70 ppm } \\
\text { aliphatic and aromatic ethyl } \\
\text { ethers, amino acid carbons, } \\
\text { and methyl esters of } \\
\text { carboxylic groups }\end{array}$ & 16 & 7 & 8 \\
$\begin{array}{l}\text { 70-100 ppm } \\
\text { C-H bonds, secondary } \\
\text { alcohols, and other carbon } \\
\text { atoms bound to oxygen }\end{array}$ & 12 & 8 & 7 \\
$\begin{array}{l}100-108 \text { ppm } \\
\text { cellulose anomeric carbon } \\
\text { and hemiacetal carbon }\end{array}$ & 4 & 4 & 4 \\
$\begin{array}{l}\text { 108-135 ppm } \\
\text { protonize aromatic carbon, } \\
\text { bridgehead C }\end{array}$ & 22 & 36 & 36 \\
$\begin{array}{l}135-150 \text { ppm } \\
\text { alkylaromatic }\end{array}$ & 8 & 11 & 11 \\
$\begin{array}{l}150-170 \text { ppm } \\
\text { aromatic C of fenols and } \\
\text { fenol esters }\end{array}$ & 8 & 13 & 12 \\
$\begin{array}{l}170-190 \text { ppm } \\
\text { carboxyl group and amidic } \\
\text { carbonyl }\end{array}$ & 3 & 5 & 4 \\
\hline
\end{tabular}


on the upper humus horizon and litter, the burning of which leads to organic matter mineralization.

According to ignition loss values, there was carbon loss in the surface soil horizons due to the destruction of organic horizons, mineralization of root residues and an almost complete absence of new litter which would serve as material for humification.

The SOM content showed that surface fires influence soil more intensively than crown fires. However, if the crown fire resulted from the surface fire, and the impact on the soil cover consisted of a direct effect and an influence of the surface fire, why was the crown fire less destructive? A crown fire includes burning of the upper part of the soil observed in a surface fire, but with subsequent burning of crowns. Perhaps the increase in carbon content in crown fires is connected with the large amount of charred tree remains in the soil.

As for group humus composition of studied soils, some authors have noted an increase in humic acid content and a decrease in the carbon-to-nitrogen ratio (Abakumov and Frouz, 2009; Efremova and Efremov, 2006). On the contrary, the appearance of the most aggressive fractions presented by fulvic acids was recorded in other studies (Dobrovol'skij, 2002). In our case, the litter of the control plot was characterized by a fulvic-humic type of humus (for the other horizons, humic-fulvic) and an increase in humic acids, which was especially strong after the surface fire, as characteristic of postpyrogenic soils. A reduction of the $\mathrm{C}_{\mathrm{ha}} / \mathrm{C}_{\mathrm{fa}}$ ratio due to new plant litter was observed in the following years. An increase in humic acid content was also observed in the humus horizon.

As a result of fires, humic acid content in the postpyrogenic horizons clearly increased. After surface fire, there was an increase in the degree of SOM humification. After one year, the degree of SOM humification in the surface fire plot leveled and reached control values, whereas in the crown fire plot without litter the content of humic acids increased.

Nitrogen enrichment of humus is characterized by the $\mathrm{C} / \mathrm{N}$ ratio. This indicator does not give information about the forms of nitrogen-containing components; besides the humic substances, both ammonium nitrogen fixed by minerals and protein components of microorganisms can influence the $\mathrm{C} / \mathrm{N}$ ratio. However, the transformation of organic residues during humification can be assessed by the values of nitrogen enrichment of humic substances. The values of the $\mathrm{C} / \mathrm{N}$ ratio change during humification and indicate the degree of SOM humification.

The rates of SOM humification and mineralization differed at the three plots. However, there was a close correlation between carbon and nitrogen levels. According to the $\mathrm{C} / \mathrm{N}$ ratio, an obvious prevalence of humification processes over mineralization occurred in the con- trol plot. The $\mathrm{C} / \mathrm{N}$ ratio decreased two-fold in the postpyrogenic plots, due to the fact that high temperatures induced the mineralization of organic residues.

Moreover, elemental analysis of humic powders was conducted for studied soils. Using the values of $\mathrm{H} / \mathrm{C}$ ratios, it is possible to identify a molecular structure of humic substances (Orlov, Sadovnikova, and Sukhanova, 2005). The H/C ratio shows that the essential parts of humic acids in control soil are aliphatic fragments. Although the quantity of aliphatic fragments after a wildfire considerably decreased, the relative amount of oxygen-containing and aromatic fragments increased; thus, the degree of aromatization of newly-formed organic matter increased after the fires. The carbon content in the humic acid molecules increased in the following order: control $\rightarrow$ surface fire $\rightarrow$ crown fire. The H/C ratio showed that the degree of hydrogenation decreased in the same order. Figure 3 shows two groups of humic acids: those of a crown fire and those of a surface fire. Dehydrogenation, especially in the case of crown fire, is a characteristic feature for these humic acids. Dehydrogenation can result from either hydrogen losses (absolute dehydrogenation) or oxidation processes (relative dehydrogenation). A low content of oxygen and reduction of the $\mathrm{O} / \mathrm{C}$ ratio testifies to the loss of peripheral fragments of humic acid molecules that changes the redox balance in these molecules. For this reason, the humic acids were characterized by negative values of oxidation. Hydrogen content decreased as a result of the fires, which is the reason for the dehydrogenation of the humic acid molecules. The crown fire led to stronger dehydrogenation (Fig. 3) due to the complete loss of hydrogen. At the same time, the amount of carbon increased in the humic acid molecules of postfire soils; this suggests that there was a partial degradation of the molecules' peripheral parts, which would be another reason for dehydrogenation. Thus, formation of the hardly hydrolyzable "black carbon" component - the highly-aromatic substances formed as a result of oxidative processes - is obvious.

The simultaneous reduction in the $\mathrm{H} / \mathrm{C}$ and $\mathrm{O} / \mathrm{C}$ atomic ratios after the wildfires indicates an essential loss of oxygen-containing functional groups and an extension of the degree of aromaticity. Caused by high temperature, polymerization and dehydrogenation lead to an accumulation of a large number of aromatic structures, including nitrogen-containing heterocyclic compounds (Gonzalez-Perez, González-Vila, Almendros, and Knicker, 2004; Schulze, Wirth, and Heimann, 2000; Almendros, Gonzalez-Vila, and Martın, 1990). An increase in the $\mathrm{O} / \mathrm{C}$ ratio and the extent of oxidation is characteristic of the humic powders of 2012 and 2014.

The nitrogen content in the humic acids (as shown by the $\mathrm{C} / \mathrm{N}$ ratio) decreased as a result of the wildfires. There was also a transformation of structure and composition of the molecules, diagnosed by an obvious al- 
teration in the extent of oxidation (testifying to dehumification after wildfire), a decrease in the $\mathrm{O} / \mathrm{C}$ ratio and an increase in the nitrogen content of the humic acid molecules. This probably happened due to nitrogen heterocyclic formation. The decrease in the extent of oxidation points toward the development of aromatic structures in the humic acids after wildfires, especially after crown fires.

According to the values derived by the Aliev formula (1), the caloric content of humic acids in the control plot is the smallest, while humic acids of postfire soils are characterized by increased caloric content, which corresponds with decreasing of content of oxygen-containing groups and reduction of $\mathrm{O} / \mathrm{C}$ ratio. It is probably in connection with this that there is a significant, up to sixfold, increase in high-caloric soil lipids fraction after wildfires (Almendros, Gonzalez-Vila, and Martın, 1990). Another possible explanation is that the caloric content of HA molecules increases due to a relative decrease of oxygen content, because in case of oxidation, oxygen atoms, which are a part of the molecules, play a vital role, reducing the general caloric content of organic matter. At the same time, Mendeleev's formula (2) more clearly reflects a decrease of caloric values in the order: control $\rightarrow$ crown fire $\rightarrow$ surface fire. There is a decrease of caloric content due to release of heat at any heating. It allows the conclusion that it is quite logical to use D. I. Mendeleev's formula for postfire soils, especially as it was developed for fuel materials. However, for the humic acids extracted from control soils it is more correct to use S. A. Aliev's formula, in which HA behave as well oxidized compounds.

The charts in Figures 3, 4 and 5, constructed on the basis of Table 4, demonstrate that humic acids in control soils and after wildfires form heterogeneous groups. The main difference is the ratio of hydrogen, oxygen and carbon.

Thus, there is a simultaneous reduction of atomic ratios $\mathrm{H} / \mathrm{C}$ and $\mathrm{O} / \mathrm{C}$ at high temperatures, which indicates a slight loss of oxygen-containing functional groups (losses at crown fires are bigger), whereas a degree of molecule aromatization increases.

Soil organic matter is characterized by the presence of two essentially different groups of compounds: the most conservative, stable part is actually humic substances, whereas the significantly more mobile and available for microbial decomposition part is labile compounds. Water-soluble labile forms of SOM quickly reflect soil processes in changes of its composition and properties.

Both the absolute and relative content of water-soluble organic substance decreases under pyrogenic effect. Differences between the post-fire and control plots were found to be statistically significant, but the differences between different types of fires were not. Also, it is ap- propriately coordinated with the minimum values of biological activity (Maksimova and Abakumov 2015) in upper soil horizons affected by fires and lower $\mathrm{C} / \mathrm{N}$ ratio noted in the same samples. These results testify to the decrease of ecological soil stability after wildfires, and, as a result, considerably greater vulnerability of these soils in case of possible future fires.

In general, crown and surface fire plots are not very different in terms of ${ }^{13} \mathrm{C}-\mathrm{NMR}$ spectra of humic acids; however, humic acids of the control plot have essential differences from those of the pyrogenic plots (Table 7 , Fig. 6). As a result of wildfires, methyl group of aliphatic and aromatic ethyl ethers, amino acid carbons, and methyl esters of carboxylic groups decrease, and the content of the following groups slightly decreases: alkyl methyls and $\mathrm{CH}_{2}$ units, quarternal carbon and $\mathrm{CH}$ carbons and $\mathrm{C}-\mathrm{H}$ bonds, secondary alcohols, and other carbon atoms bound to oxygen. But the content of protonize aromatic carbon, bridgehead $\mathrm{C}$ and aromatic $\mathrm{C}$ of fenols and fenol esters increases in postpyrogenic plots. These results correspond with data of the elemental analysis of humic acids regarding the fact that wildfires cause an essential loss of oxygen-containing functional groups and an accumulation of a large number of aromatic structures.

Thus, the humic acids in soils affected by wildfires and in control soils form very diverse groups. The main effect of fire on humic molecules composition is an increase of aromaticity and decrease of aliphatic compounds content. This could lead to illusory conclusions about the increasing of SOM stability, but taking into account that aromaticity increases relatively due to heating and combustion losses of the most degradable parts of molecules, this suggested conclusion may not be so realistic.

\section{Conclusions}

Catastrophic 2010 wildfires in the forests of Tolyatti resulted in the formation of pyrogenic-transformed soils which significantly differ from control soils in morphological characteristics and basic chemical and physical properties.

Fire impact in cases of surface and crown scenarios changes soil properties in various scenarios. In particular, surface fire has a stronger effect on carbon content due to more complete combustion of litter and upper humus horizons, and it also leads to consolidation of the upper soil layers. An increase of humic acids is observed in humus of postpyrogenic soils.

The content of labile water-soluble humus significantly decreases after wildfires. During the fire, mineralization of organic residues occurs, which results in changes of the $\mathrm{C} / \mathrm{N}$ ratio. A decrease of the oxygen, nitrogen, hydrogen and carbon atoms content in SOM and humic 
acids was observed. Pyrogenic influence leads to an increase of aromaticity degree, loss of oxygen-containing groups, and also to dehydrogenation of molecules. According to ${ }^{13} \mathrm{C}$-NMR spectra, the aromaticity degree of humic acids molecules significantly increases as a result of wildfires, and the content of aliphatic part decreases.

Some years after wildfires, many of the changes in properties of postpyrogenic soils decrease and begin to approach control levels. Postfire soil dynamics are observed, expressed by a reduction of $\mathrm{pH}$ in the upper horizons due to leaching of the alkali, as well as humus accumulation with new plant residues. However, in the case of surface fire, the main factor of postfire soil dynamics is new plant litter on the soil surface, whereas after crown fire a driving force is surface water erosion. Both of these factors influence, to different degrees, postpyrogenic changes of the main soil properties over time.

\section{Acknowledgements}

The authors offer their thanks to the director of the Institute of Ecology of the Volga River Basin of the Russian Academy of Sciences (IEVB RAS), Dr. Professor G.S. Rosenberg, to the deputy director for science of IEVB RAS, Dr. Professor S. V. Saksonov, and to Dr. S. A. Senator, for their help in the organization of work and research support.

\section{References}

Abakumov, E. V. 2009. Elemental composition and structural features of humic substances in young podzols developed on sand quarry dumps. European Journal of Soil Science 42(6):616-622. https://doi.org/10.1134/ S1064229309060052

Abakumov, E. V., and Frouz, I. 2009. Evolution of the soil humus status on the calcareous Neogene clay dumps of the Sokolov quarry complex in the Czech Republic. European Journal of Soil Science 42(7):718-724. https://doi. org/10.1134/S1064229309070023

Abakumov, E. V., Maksimova, E. Yu., Lagoda, A. V., and Koptseva, E. M. 2011. Soil formation in the quarries for limestone and clay production in the Ukhta region. European Journal of Soil Science 44(4):380-385. https://doi. org/10.1134/S1064229311040028

Alexis, M. A., Rumpel, C., and Knicker, H. 2010. Thermal alteration of organic matter during a shrubland fire: A field study. Organic Geochemistry 41(7):690-697. https://doi. org/10.1016/j.orggeochem.2010.03.003

Almendros, G., Gonzalez-Vila, F. J., and Martın, F. 1990. Fire-induced transformation of soil organic matter from an oak forest: an experimental approach to the effects of fire on humic substances. Soil Science 149:158-168. https:// doi.org/10.1097/00010694-199003000-00005

Antipova, A. V., and Prokhorova, N. V. 2012. Analysis of postpyrogenic processes in natural and artificial pine forests in Samara oblast. Vestnik Samarskogo Gosudarstvennogo Universiteta, Estestvennonauch. Ser. Biol. 3/1 (94): 173-179.

Baldock, J. A., and Smernik, R. J. 2000. Chemical composition and bioavailability of thermally altered Pinus resinosa (Red pine) wood. Organic Geochemistry 33:1093-1109. https://doi.org/10.1016/S0146-6380(02)00062-1

Bergeron, S. P., Bradley, R. L., Munson, A., and Parsons, W. 2013. Physico-chemical and functional characteristics of soil charcoal produced at five different temperatures.
Soil Biology and Biochemistry 58:140-146. https://doi. org/10.1016/j.soilbio.2012.11.017

Bodi, M., Martin, D. A., Santin, C., Balfour, V., Doerr, S. H., Pereira, P., Cerda, A., and Mataix-Solera, J. 2014. Wildland fire ash: production, composition and eco-hydrogeomorphic effects. Earth-Science Reviews 130:103-127. https://doi.org/10.1016/j.earscirev.2013.12.007

Cerdà, A., and Doerr, S. H. 2008. The effect of ash and needle cover on surface runoff and erosion in the immediate post-fire period. Catena 74:256-263. https://doi. org/10.1016/j.catena.2008.03.010

Cerli, C., Celi, L., Kaiser, K., Guggenberger, G., Johansson, M.-B., and Cignetti, A. 2008. Changes in humic substances along an age sequence of Norway spruce stands planted on former agricultural land. Organic Geochemistry 39(9):1269-1280. https://doi.org/10.1016/j.orggeochem.2008.06.001

Certini, G. 2005. Effects of fire on properties of forest soils: a review. Oecologia 143:1-10. https://doi.org/10.1007/ s00442-004-1788-8

Certini, G. 2014. Fire as a soil-forming factor. Ambio 43(2):191195. https://doi.org/10.1007/s13280-013-0418-2

Certini, G., Nocentini, C., and Knicker, H. 2011. Wildfire effects on soil organic matter quantity and quality in two fire-prone Mediterranean pine forests. Geoderma 167-168:148-155. https://doi.org/10.1016/j.geoderma.2011.09.005

Cleland, T. M. 2004. The Munsell Color System. A practical description with suggestions for its use. USA: 3rd Edition, Kessinger Publishing, Whitefish, Mont.

Diaz-Ravina, M. 1996. Bacterial activity in a forest soil heating and organic amendments measured by the thymidine and leucine incorporation techniques. Soil Biology and Biochemistry 28:419-426.

Dobrovol'skij, G. V. 2002. Soil degradation and conservation. Moscow: Mosk. Gos. Univ. 654 pp.

Dymov, A. A., and Gabov, D. N. 2015. Pyrogenic alterations of Podzols at the North-east European part of Russia: Morphology, carbon pools, PAH content. Geoderma 241-242:230237. https://doi.org/10.1016/j.geoderma.2014.11.021

Efremova, T. T., and Efremov, S. P. 2006. Pyrogenic transformation of peat-forest SOM. European Journal of Soil Science 12:1441-1450.

Gonzalez-Perez, J. A., Gonza' lez-Vila, F. J., Almendros, G., and Knicker, H. 2004. The effect of fire on soil organic matter - a review. Environment International 30:855-870. https://doi.org/10.1016/j.envint.2004.02.003

Guénon, R., Vennetier, M., Dupuy, N., Roussos, S., Pailler, A., and Gros, R. 2013. Trends in recovery of Mediterranean soil chemical properties and microbial activities after infrequent and frequent wildfires. Land Degradation \& Development 24:115-128. https://doi.org/10.1002/ldr.1109.

Huggett, R.J. 1998. Soil chronosequences, soil development, and soil evolution: a critical review. Catena 32(3-4):155172. https://doi.org/10.1016/S0341-8162(98)00053-8

Jain, T.B., Pilliod, D.S., Graham, R.T., Lentile, L. B., and Sandquist, J. E. 2012. Index for characterizing post-fire soil environments in temperate coniferous forests. Forests 3:445-466. https://doi.org/10.3390/f3030445.

Keesstra, S., Wittenberg, L., Maroulis, J., Sambalino, F., Malkinson, D., Cerdà, A., and Pereira, P. 2016. The influence of fire history, plant species and post-fire management on soil water repellency in a Mediterranean catchment: The Mount Carmel range, Israel. Catena 149:857-866. https://doi.org/10.1016/j.catena.2016.04.006.

Knicker, H. 2007. How does fire affect the nature and stability of soil organic nitrogen and carbon? A review. Biogeochemistry 85:91-118. https://doi.org/10.1007/s10533007-9104-4. 
Lodygin, E. D. 2016. Structural and functional parameters of humic substances of taiga and tundra soils at the European North-East of Russia. - Dr. Sci. dissertation abstract, Moscow, $48 \mathrm{pp}$.

Maksimova, E., and Abakumov, E. 2015. Wildfire effects on ash composition and biological properties of soils in foreststeppe ecosystems of Russia. Environmental Earth Sciences 74:4395-4405. https://doi.org/10.1007/s12665-015-4497-1.

Mastrolonardo, G., Francioso, O., Di Foggia, M., Bonora, S. Forte, C., and Certini, G. 2015. Soil pyrogenic organic matter characterization by spectroscopic analysis: a study on combustion and pyrolysis residues. Journal of Soils and Sediments 15(4):769-780. https://doi.org/10.1007/ s11368-014-1034-x.

Mataix-Solera, J., Cerdà, A., Arcenegui, V., Jordán, A., and Zavala, L. M. 2011. Fire effects on soil aggregation: a review. Earth-Science Reviews 109:44-60. http://dx.doi. org/10.1016/j.earscirev.2011.08.002.

Methods of Soil Analysis. Part 3 Chemical Methods. 1996. Wisconsin, USA: Soil Science Society of America Inc., American Society of Agronomy Inc. 677, South Segoe Road, Madison.

Michelloti, L. A., and Miesel, J.R. 2015. Source material and concentration of wildfire-produced pyrogenic carbon influence post-fire soil nutrient dynamics. Forests 6:13251342. https://doi.org/10.3390/f6041325.

Mol, G., and Keesstra, S. D., 2012. Soil science in a changing world. Current Opinions in Environmental Sustainability 4:473-477.

Munsell, A. H. 1912. A Pigment Color System and Notation. The American Journal of Psychology (University of Illinois Press) 23(2):236-244.

Nadporozhskaya, M. A., Mohren, G. M. J., Chertov, O. G., Komarov, A. S., and Mikhailov, A. V. 2006. Dynamics of soil organic matter in primary and secondary forest succession on sandy soils in The Netherlands: An application of the ROMUL model. Ecological Modelling 190:399-418. https://doi.org/10.1016/j.ecolmodel.2005.03.025

Orlov, D. S. 1985. Soil Chemistry. Moscow: Mosk. Gos. Univ. [in Russian].

Orlov, D. S., and Grishina, L. A. 1981. Laboratory Manual on Humus Chemistry. Moscow: Moscow State University Press [in Russian].

Orlov, D. S., Sadovnikova, L. K., and Sukhanova, N. I. 2005. Soil chemistry. Moscow: «High school», $558 \mathrm{pp}$.

Pereira, P., Cerdà, A., Úbeda, X., Mataix-Solera, J., Arcenegui, V., and Zavala, L. 2015. Modelling the impacts of wildfire on ash thickness in a short-term period. Land Degradation and Development 26:180-192. https://doi. org/10.1002/ldr.2195

Pereira, P., Ubeda, X., Martin, D. A., Mataix-Solera, J., Oliva, M., and Novara, A. 2014. Short-term spatio-temporal spring grassland fire effects on soil colour, organic matter and water repellency in Lithuania. Solid Earth 5:209-225. https://doi.org/10.5194/sed-5-2119-2013

Pereira P., Rein G., and Martin D. 2016. Editorial: Past and Present Post-Fire Environments. Science of the Total Environment 573:1275-1277. https://doi.org/10.1016/j.scitotenv.2016.05.040

Schnitzer, M. 1982. Organic matter characterization. In: Page BL, Miller RH, Keeney DR (eds) Methods of soil analysis, Part 2, chemical and microbiological properties. Agronomy monograph 9, Soil Science Society of America, Madison, 581-594.

Schulze, E. D., Wirth, C., and Heimann, M. 2000. Managing forests after Kyoto. Science 289:2058-2059. https://doi. org/10.1126/science.289.5487.2058

Shishov, L. L., and Tonkonogov, V. D. 2004. Classification and diagnostics of Russian soils. Moscow, Russia: Soil institute of Dokuchayev, $341 \mathrm{pp}$.

Sorokin, N. D. 1983. The impact of forest wildfires on biological activity of soils. Lesovedenie 4:24-28.

Van Eck, C. M., Nunes, J. P., Vieira, D., Keesstra, S., and Keizer, J. J. 2016. Physically-Based Modelling of the Post-Fire Runoff Response of a Forest Catchment in Central Portugal: Using Field versus Remote Sensing Based Estimates of Vegetation Recovery. Land Degradation and Development 27(5):1535-1544. https://doi.org/10.1002/ldr.250

Vasil'evskaya, V. D., Ivanov, V. V., and Bogatyrev, L. G. 1986. Soils of the North of Western Siberia. Moscow: Moscow State University Press. [in Russian].

Vorobyova, L. A. 2006. Theory and practice of the chemical soil analysis. Moscow, Russia: GEOS, 400 pp.

Zenova, G. M., Kozhevin, P.A., Manucharova, N.A., Dubrova, M. S., and Zvyagintsev, D. G. 2012. Temperature as a factor of development of psychrotolerant mycelial bacteria complexes in soils of northern regions. Biology Bulletin 39:416-422.

Zhao, H., Tong, D. Q., Lin, Q., Lu, X., and Wang, G. 2012. Effect of fires on soil organic carbon pool and mineralization in a Northeastern China wetland. Geoderma 189-190:532539. https://doi.org/10.1016/j.geoderma.2012.05.013

Zikeev, T. A., and Korelin, A. I. 1948. Analysis of Power Fuel. Moscow [in Russian]. 